Aqlania, Vol. 08. No. 02 (Juli-Desember) 2017

ISSN: 2087-8613

\title{
KERUKUNAN DALAM PERSPEKTIF AGAMA-AGAMA DI \\ INDONESIA
}

Syafi'in Mansur

\section{Abstrak}

Fenomena kerukunan atau toleransi umat beragama di Indonesia memang menarik diamati karena kerukunan umat beragama di Indonesia dapat tumbuh subur dengan agama-agama yang bermacam-macam, ada Islam, Kristen [Katolik dan Protestan], Hindu, Buddha dan Khonghucu. Namun tetap semua agama sama-sama menjaga umatnya untuk menjadi rukun, damai, kasih sayang dan saling menghormati dan menghargai. Bahkan Indonesia bisa menjadi contoh bagi dunia tentang toleransi atau kerukunan yang dapat tumbuh dengan keragamaan atau khebinekaan. Begitu pula, para tokoh agama saling bahu-membahu dalam menciptakan kerukunan atau toleransi di Indonesia.

Kata Kunci: Kerukunan, perspektif, agama Islam, Kristen [Katolik dan Protestan], Hindu, Buddha, Konghucu dan Indonesia

\section{A. Pendahuluan}

Berbicara tentang kerukunan tidak asing lagi di telinga bangsa Indonesia karena sejak bangsa Indonesia merdeka hingga kini sudah diusung dan diatur dengan baik tentang kerukunan umat beragama sehingga lahir konsep triologi kerukunan, yaitu kerukunan interen umat 
beragama, kerukunan antarumat beragama dan kerukunan antara umat beragama dengan pemerintah. ${ }^{1}$ Kerukunan umat beragama tersebut, terus-menerus digalakkan oleh Pemerintah untuk menjaga kedamaian, harmonisasi dan saling menghormati di Republik Indonesia tercinta ini. Dengan banyaknya agama yang diakui oleh Pemerintah secara resmi adalah agama Islam, agama Kristen [Katolik dan Protestan], agama Hindu, agama Buddha dan agama Konghuchu. Semua agama itu, dianut dan diyakini oleh rakyat bangsa Indoensia.

Bangsa Indonesia sudah mengenal dengan baik dan mempraktekkan dalam kehidupan beragama dengan rukun dan damai. Hal ini, ditegaskan oleh Umar Hasyim bahwa telah terkenal sejak dahulu di mana-mana, watak bangsa Indonesia adalah rukun, saling menghormati dan saling mengerti satu sama lain. Tenggang rasa antara sesama, bergotong royong di dalam membangun masyarakat dalam kehidupan sehari-hari dan juga merupakan ciri khas dari bangsa Indonesia. ${ }^{2}$ Memang benar, bahwa bangsa Indonesia adalah bangsa yang beradab dan bangsa yang rukun, suka gotong royong dan saling menghargai dan menghormati. Kalau hal ini, dipraktekkan dan difahami dengan benar di bangsa Indonesia maka kerukunan umat beragama itu akan terlaksana dengan

${ }^{1}$ Sudirman Tebba, Islam Pasca Orde Baru, \{Yogyakarta: Tiara Wacana Yogya, 2001\}, cet. ke-1, hlm. 143

${ }^{2}$ Umar Hasyim, Toleransi dan Kemerdekaan Beragama dalam Islam Sebagai Dasar Menuju Dialog dan Kerukunan Antar Agama, \{Surabaya: Bina Ilmu, 1979\}, hlm. 359

Aqlania, Vol. 08, No. 02 (Juli-Desember) 2017 ISSN: 2087-8613 
benar dan tidak akan terjadi konflik di antara umat beragama. Apalagi semua agama yang dipercayai oleh bangsa Indonesia tersebut, mengajarkan kedamaian dan cinta kasih sesama manusia.

Dalam kaitan ini, Alwi Shihab menegaskan bahwa perbedaan suku dan keyakinan beragamanya. Indonesia disifati oleh tradisi pluralisme yang luar biasa dan tidak dapat dipungkiri lagi. Umat agama Hindu, Buddha, Islam, Kristen dan Konghuchu hidup bersama. Sebagian besar, dengan harmonis sebagai saudara di bawah payung Republik Indonesia. Dengan adanya karakter mosaic latar belakang budaya Indonesia, lewat sejarah panjang mereka, rakyat Indonesia telah hidup dengan takaran kerukunan dan keharmonisan yang baik. Tentu saja ada perselisihan, tetapi segera diselesaikan dalam semangat hubungan persaudaraan. Dengan sejarah panjang kerukunan antaragama, antarsuku dan antarbudayanya. Indonesia bisa menjadi contoh yang baik, tidak saja bagi dunia Islam tetapi dunia secara umum. ${ }^{3}$

Memang dunia mengetahui bahwa Indonesia adalah dikenal dengan masyarakatnya yang religius dan dikenal pula dengan kerukunannya yang damai dan harmonis. Walaupun ada terjadi konflik dan perselisihan antara umat beragama, namun dapat teratasi dan terbentuknya aturan pemerintah yang mengatur tentang kerukunan umat

${ }^{3}$ Alwi Shihab, Islam Inklusif Menuju Sikap Terbuka dalam Beragama, \{Bandung: Mizan, 1998\}, cet. ke-2, hlm. 348 
beragama. Maka hal ini, menarik untuk diselusuri yang berkaitan dengan kerukunan dalam konsepsi agama-agama yang ada di Indonesia sehingga dengan mengetahui dan memahami akan terlaksana dengan baik bagi kerukunan di Indonesia.

B. Kerukunan Dalam Konsepsi Agama di Indonesia

Agama yang diakui secara syah oleh Negara Rapublik Indonesia adalah agama Islam, agama Kristen [Protestan dan Katolik], agama Hindu, agama Buddha dan agama Konghuchu. Semua agama tersebut, memiliki Kitab Suci yang dipercayai dan diimani oleh para pengikutnya, seperti Islam mengimani Al-Qur'an sebagai kitab sucinya, Kristen kitab sucinya adalah Alkitab atau Bibel, Hindu kitab sucinya adalah Weda, Buddha kitab sucinya adalah Tripitaka dan Konghuchu kitab sucinya adalah Susi.

Kitab suci tersebut, tentunya membicarakan tentang kerukunan sebagai landasan dalam hubungan di antara umat beragama sehingga saling menghormati dan menghargai, saling toleransi dan rukun serta saling hidup perdampingan dengan harmonis. Bahkan Syahrin Harahap menyatakan bahwa jika umat beragama bersungguh-sungguh mempelajari kitab sucinya, segera akan diketahuinya bahwa kitab sucinya mengajarkan adanya hubungan antar agama. ${ }^{4}$ Memang benar, kalau kita memahami dan mengkaji dengan baik dan mendalam kitab suci kita sendiri maka

${ }^{4}$ Syahrin Harahap, Teologi Kerukunan, \{Jakarta: Prenada Media Group, 2011\}, cet. ke-1, hlm. 58

Aqlania, Vol. 08, No. 02 (Juli-Desember) 2017 ISSN: 2087-8613 
akan menemukan ajaran tentang kerukunan antar umat beragama sebagai berikut:

1. Konsep Kerukunan Islam

Islam adalah agama kerukunan atau toleransi karena Islam hadir di Indonesia bukan dengan penjajahan melainkan dengan keramahan dan saling menghormati yang dibawa oleh para pedagang dan mubaligh muslim yang santun dan terbuka sehingga Islam di Indonesia mudah diterima oleh masyarakat Indonesia. Islam yang dibawa oleh Nabi Muhammad Saw. yang sangat toleran diterapkan di Indonesia. Hal ini, sesuai dengan petunjuk Al-Qur'an dan Sunnah Rasul yang diterapkan oleh Nabi Muhammad Saw. dan para pengikutnya, sebab Al-Qur'an dan Sunnah Rasul adalah tidak memaksakan orang lain untuk mengikuti agama Islam melainkan dengan kesadaran yang mendalam bukan dengan main-main, bahkan diberikan kebebasan untuk memilih agama sesuai dengan kehendak hatinya, mengakui keaneragaman penganut agama yang tidak dapat dipungkiri karena itu termasuk sunnahtullah, menghormati dan menghargai perbedaan keyakinan agama dan menghargai pula bagi orang yang berkomitkan terhadap agama yang dipercayai, maka Islam secara terang mengajarkan kerukunan atau toleransi ini, antara lain:

Pertama, konsep Islam dengan tegas dan jelas bahwa tidak ada paksaan kepada orang lain untuk menjadi pengikut Islam dengan cara mengajak paksa, mengajak dengan materi, mengajak dengan berbagai 
rayuan. Hal ini, tidak diperkenankan dalam ajaran Islam karena Islam adalah agama yang mengajak dan memperingatkan dengan cara yang damai dan penuh hikmah, penuh pelajaran dan argumentasi sehingga dapat diterima dengan akal yang sehat dan hati yang cernih. Karena orang yang masuk agama Islam bukan dengan cara paksaan melainkan dengan kesadaran serta atas kehendak dan hidayah Allah. Dalam kaitan ini, Allah menyatakan dalam firman-Nya:

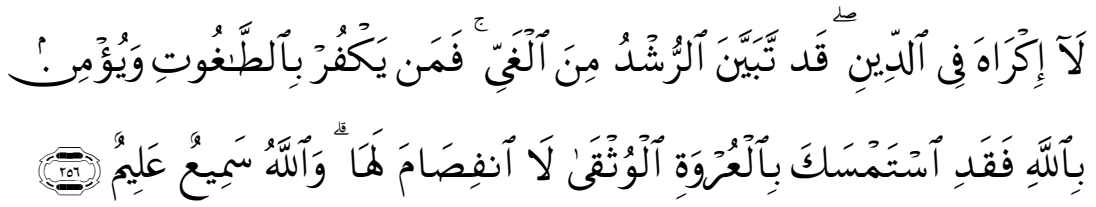

"Tidak ada paksaan untuk (memasuki) agama (Islam); Sesungguhnya telah jelas jalan yang benar daripada jalan yang sesat. karena itu Barangsiapa yang ingkar kepada Thaghut dan beriman kepada Allah, Maka Sesungguhnya ia telah berpegang kepada buhul tali yang Amat kuat yang tidak akan putus. dan Allah Maha mendengar lagi Maha mengetahui" \{QS. Al-Baqarah [2]: 256\}.

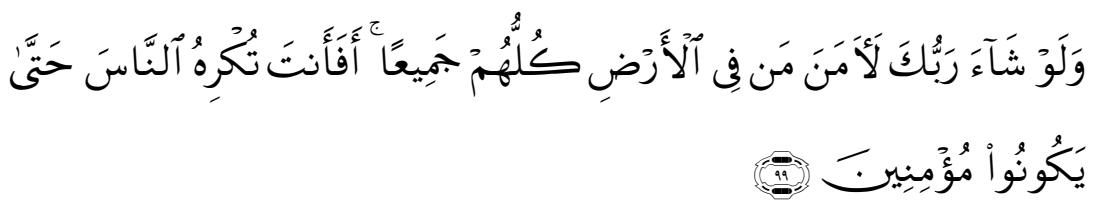

"Dan Jikalau Tuhanmu menghendaki, tentulah beriman semua orang yang di muka bumi seluruhnya. Maka Apakah kamu (hendak) memaksa 
manusia supaya mereka menjadi orang-orang yang beriman semuanya?" \{QS. Yunus [10]: 99\}.
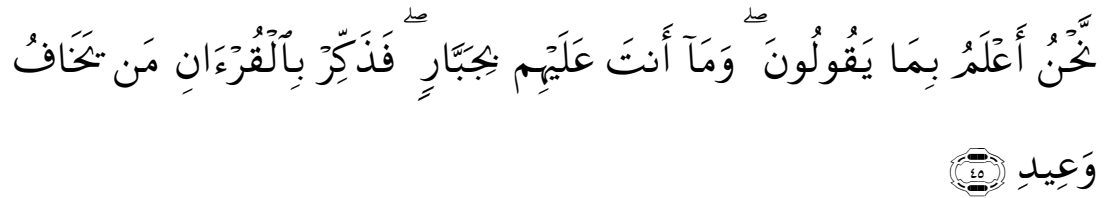

"Kami lebih mengetahui tentang apa yang mereka katakan, dan kamu sekali- kali bukanlah seorang pemaksa terhadap mereka. Maka beri peringatanlah dengan Al Quran orang yang takut dengan ancaman-Ku” \{QS. Qaf [50]: 45\}.

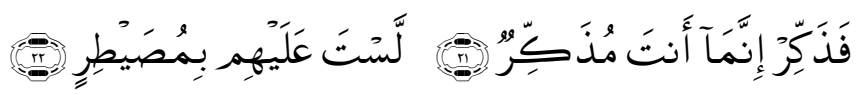

"Maka berilah peringatan, karena Sesungguhnya kamu hanyalah orang yang memberi peringatan. Kamu bukanlah orang yang berkuasa atas mereka" \{QS. Al-Ghasyiyah [88]: 21-22\}.

Kedua, konsep Islam dengan tegas dan jelas bahwa manusia telah diberikan kebebasan untuk memilih agama yang mereka yakini dan dipercayai sebagai pedoman hidupnya. Namun mereka harus bertanggung jawab dihadapan Allah karena Allahlah yang akan memutuskan itu dengan keadilan. Sebagaimana Allah menyatakan dalam firman-Nya: 


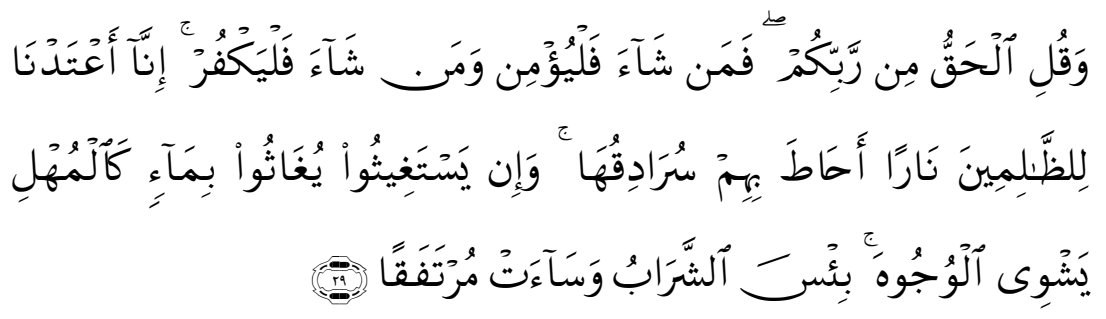

"Dan Katakanlah: "Kebenaran itu datangnya dari Tuhanmu; Maka Barangsiapa yang ingin (beriman) hendaklah ia beriman, dan Barangsiapa yang ingin (kafir) Biarlah ia kafir". Sesungguhnya Kami telah sediakan bagi orang orang zalim itu neraka, yang gejolaknya mengepung mereka. dan jika mereka meminta minum, niscaya mereka akan diberi minum dengan air seperti besi yang mendidih yang menghanguskan muka. Itulah minuman yang paling buruk dan tempat istirahat yang paling jelek" \{QS. Al-Kahfi [18]: 29\}.

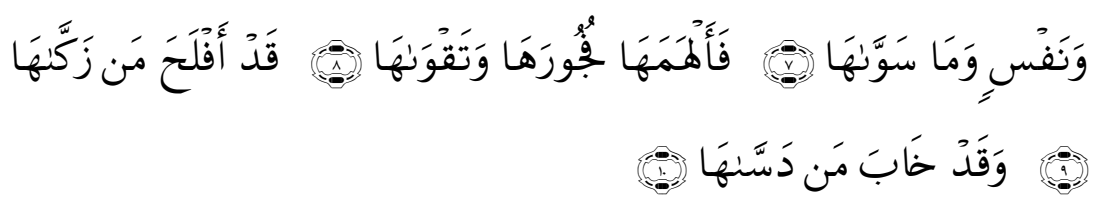

"Dan jiwa serta penyempurnaannya (ciptaannya). Maka Allah mengilhamkan kepada jiwa itu (jalan) kefasikan dan ketakwaannya. Sesungguhnya beruntunglah orang yang mensucikan jiwa itu. Dan Sesungguhnya merugilah orang yang mengotorinya" \{QS. Asy-Syams [91]: 7-10\}.

Ketiga, konsep Islam dengan tegas dan jelas bahwa ada keaneragaman penganut agama atau kemajemukan beragama yang 
dipercayai dan dianut oleh masyarakat sehingga perlu untuk saling memahami dan menghormati atas kemajemukan karena hal itu termasuk sunnahtullah dan tidak dapat dimungkiri kenyataan ini. Dalam kaitan ini, Allah menyatakan dalam firman-Nya:

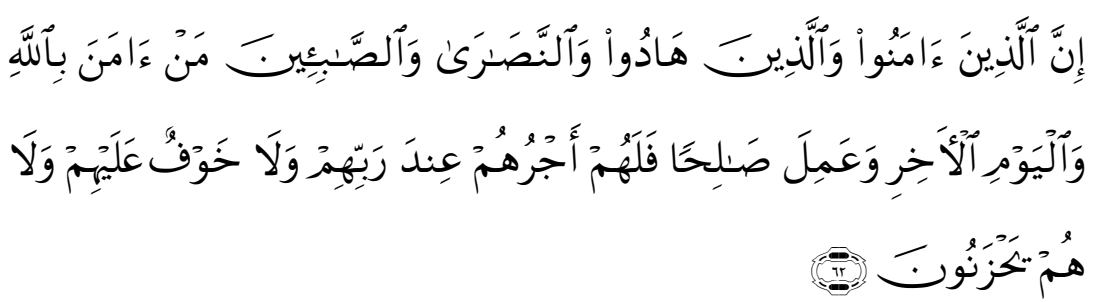

"Sesungguhnya orang-orang mukmin, orang-orang Yahudi, orang-orang Nasrani dan orang-orang Shabiin, siapa saja diantara mereka yang benarbenar beriman kepada Allah, hari kemudian dan beramal saleh, mereka akan menerima pahala dari Tuhan mereka, tidak ada kekhawatiran kepada mereka, dan tidak (pula) mereka bersedih hati" [QS. Al-Baqarah [2]: 62].

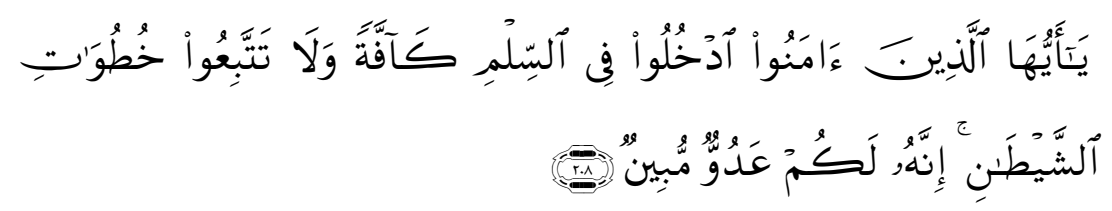

"Hai orang-orang yang beriman, masuklah kamu ke dalam Islam keseluruhan, dan janganlah kamu turut langkah-langkah syaitan. Sesungguhnya syaitan itu musuh yang nyata bagimu" \{QS. Al-Baqarah [2]: 208\}. 


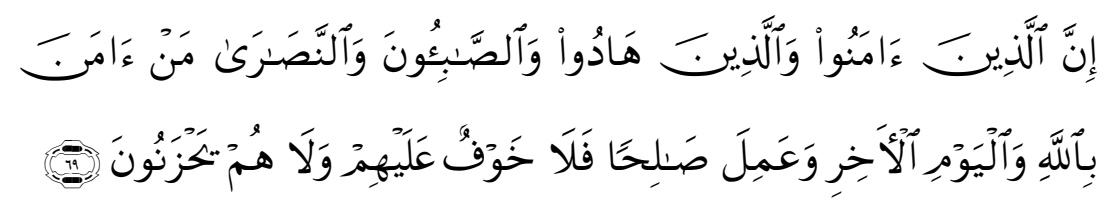

"Sesungguhnya orang-orang mukmin, orang-orang Yahudi, Shabiin dan orang-orang Nasrani, siapa saja (diantara mereka) yang benar-benar saleh, Maka tidak ada kekhawatiran terhadap mereka dan tidak (pula) mereka bersedih hati" \{QS. Al-Maidah [5]: 69\}.

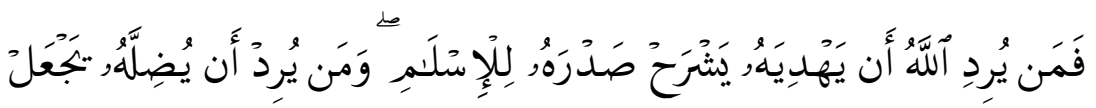

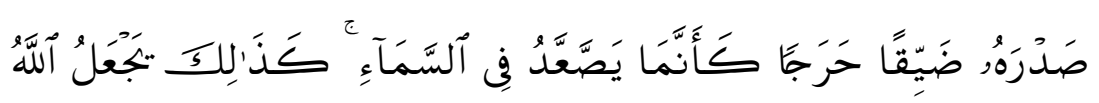

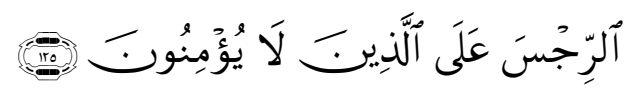

"Barangsiapa yang Allah menghendaki akan memberikan kepadanya petunjuk, niscaya Dia melapangkan dadanya untuk (memeluk agama) Islam. dan Barangsiapa yang dikehendaki Allah kesesatannya, niscaya Allah menjadikan dadanya sesak lagi sempit, seolah-olah ia sedang mendaki langit. Begitulah Allah menimpakan siksa kepada orang-orang yang tidak beriman" \{QS. Al-An'am [6]: 125\}.

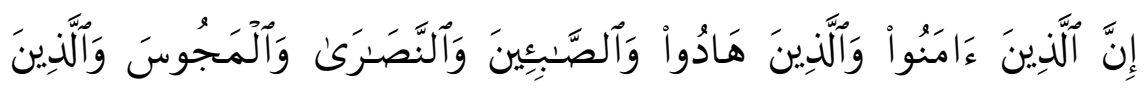

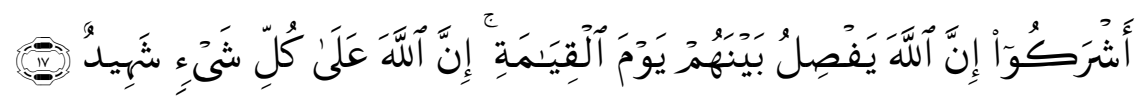
"Sesungguhnya orang-orang yang beriman, orang-orang Yahudi, orangorang Shaabi-iin, orang-orang Nasrani, orang-orang Majusi dan orang- 
orang musyrik, Allah akan memberi keputusan di antara mereka pada hari kiamat. Sesungguhnya Allah menyaksikan segala sesuatu" \{QS. AlHajj [22]: 17\}.

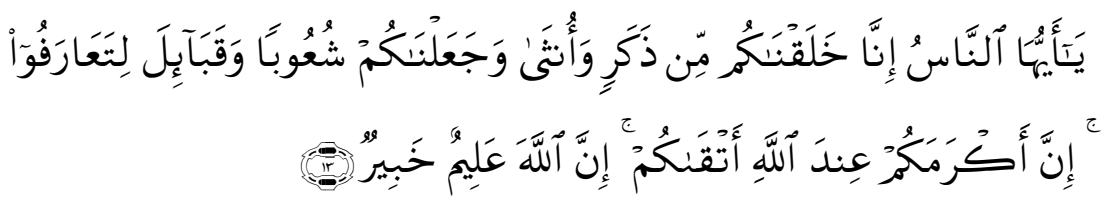

"Hai manusia, Sesungguhnya Kami menciptakan kamu dari seorang lakilaki dan seorang perempuan dan menjadikan kamu berbangsa - bangsa dan bersuku-suku supaya kamu saling kenal-mengenal. Sesungguhnya orang yang paling mulia diantara kamu disisi Allah ialah orang yang paling taqwa diantara kamu. Sesungguhnya Allah Maha mengetahui lagi Maha Mengenal" \{QS. Al-Hujurat [49]: 13\}.

Keempat, konsep Islam dengan tegas dan jelas bahwa saling menghormati dan menghargai atas keanekaragaman keyakinan agama yang dianut oleh manusia serta tidak memaksakan keyakinan orang lain untuk tukar-menukar atau perkgantian untuk beribadah kepada Tuhan agama yang lain dan juga tidak diperkenankan untuk saling mengejek satu sama lainnya. Allah menyatakan dengan firman-Nya.

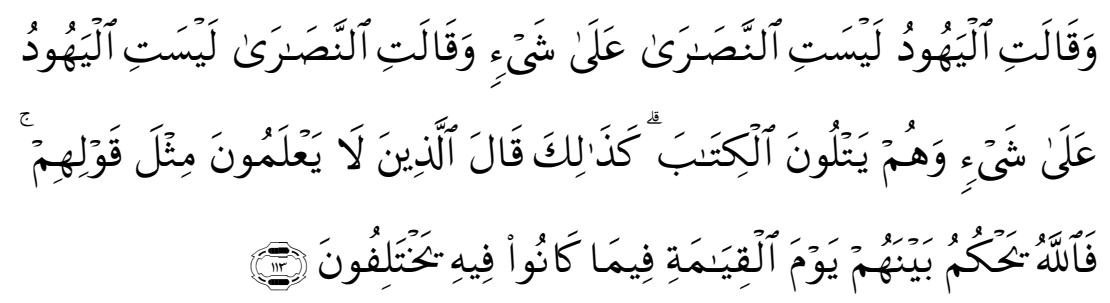


"Dan orang-orang Yahudi berkata: "Orang-orang Nasrani itu tidak mempunyai suatu pegangan", dan orang-orang Nasrani berkata: "Orangorang Yahudi tidak mempunyai sesuatu pegangan," Padahal mereka (sama-sama) membaca Al Kitab. demikian pula orang-orang yang tidak mengetahui, mengatakan seperti Ucapan mereka itu. Maka Allah akan mengadili diantara mereka pada hari kiamat, tentang apa-apa yang mereka berselisih padanya" \{QS. Al-Baqarah [2]: 113\}.

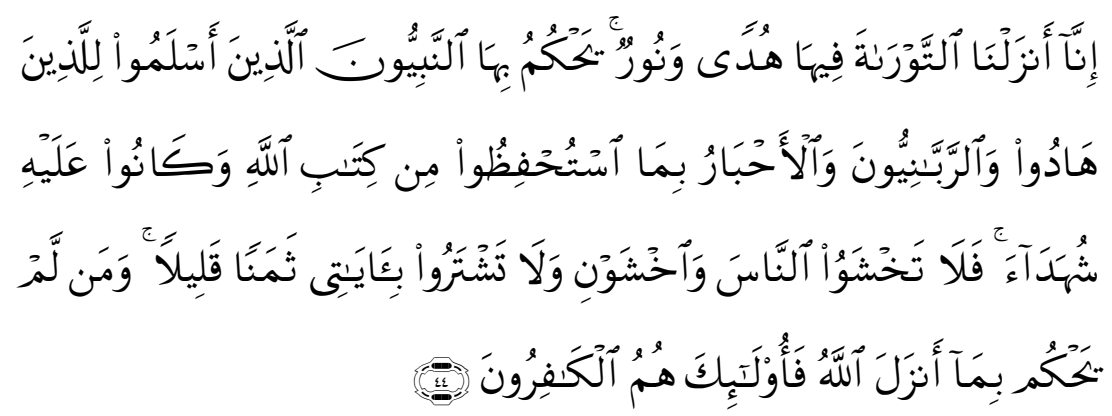

"Sesungguhnya Kami telah menurunkan kitab Taurat di dalamnya (ada) petunjuk dan cahaya (yang menerangi), yang dengan kitab itu diputuskan perkara orang-orang Yahudi oleh nabi-nabi yang menyerah diri kepada Allah, oleh orang-orang alim mereka dan pendeta-pendeta mereka, disebabkan mereka diperintahkan memelihara Kitab-Kitab Allah dan mereka menjadi saksi terhadapnya. karena itu janganlah kamu takut kepada manusia, (tetapi) takutlah kepada-Ku. dan janganlah kamu menukar ayat-ayat-Ku dengan harga yang sedikit. Barangsiapa yang tidak 
memutuskan menurut apa yang diturunkan Allah, Maka mereka itu adalah orang-orang yang kafir" \{QS. Al-Maidah [5]: 44\}.

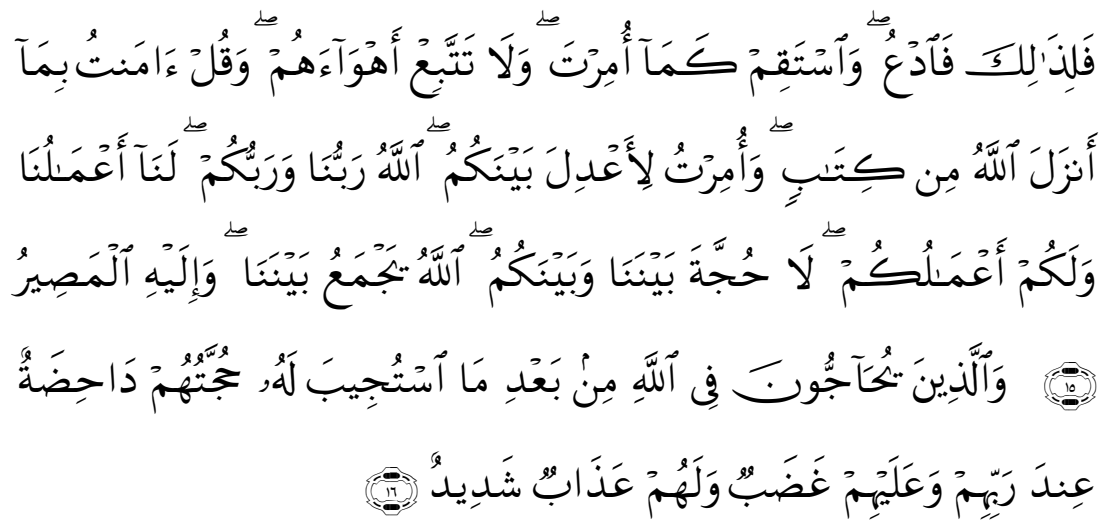

"Maka karena itu serulah (mereka kepada agama ini) dan tetaplah sebagai mana diperintahkan kepadamu dan janganlah mengikuti hawa nafsu mereka dan Katakanlah: "Aku beriman kepada semua kitab yang diturunkan Allah dan aku diperintahkan supaya Berlaku adil diantara kamu. Allah-lah Tuhan Kami dan Tuhan kamu. bagi Kami amal-amal Kami dan bagi kamu amal-amal kamu. tidak ada pertengkaran antara Kami dan kamu, Allah mengumpulkan antara kita dan kepada-Nyalah kembali (kita)". Dan orang-orang yang membantah (agama) Allah sesudah agama itu diterima Maka bantahan mereka itu sia-sia saja, di sisi Tuhan mereka. mereka mendapat kemurkaan (Allah) dan bagi mereka azab yang sangat keras" \{QS. Asy-Syura [42]: 15-16\}. 


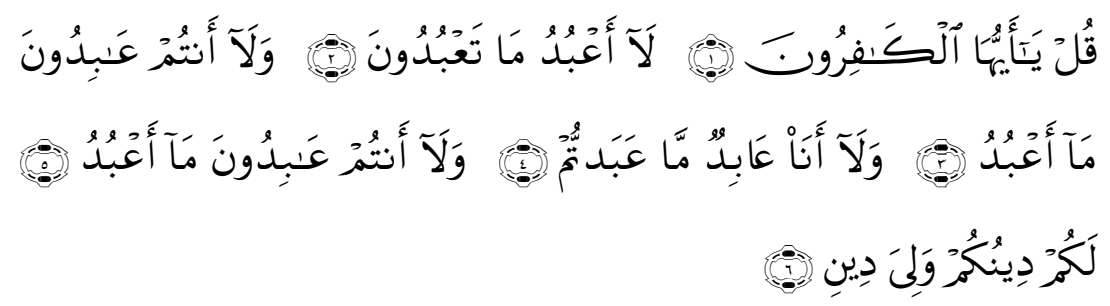

"Katakanlah: "Hai orang-orang kafir. Aku tidak akan menyembah apa yang kamu sembah. Dan kamu bukan penyembah Tuhan yang aku sembah. Dan aku tidak pernah menjadi penyembah apa yang kamu sembah. Dan kamu tidak pernah (pula) menjadi penyembah Tuhan yang aku sembah. Untukmu agamamu, dan untukkulah, agamaku" \{QS. AlKafirun [109]: 1-6\}.

Kelima, konsep Islam dengan tegas dan jelas bahwa harus berlomba dalam hal kebaikan tetapi tidak diperkenankan dalam hal keburukan. Mengerjakan Kebaikan dalam kehidupan sosial, kepentingan kemanusiaan dan kebaikan dalam berkeadilan. Allah menyatakan dalam firman-Nya.

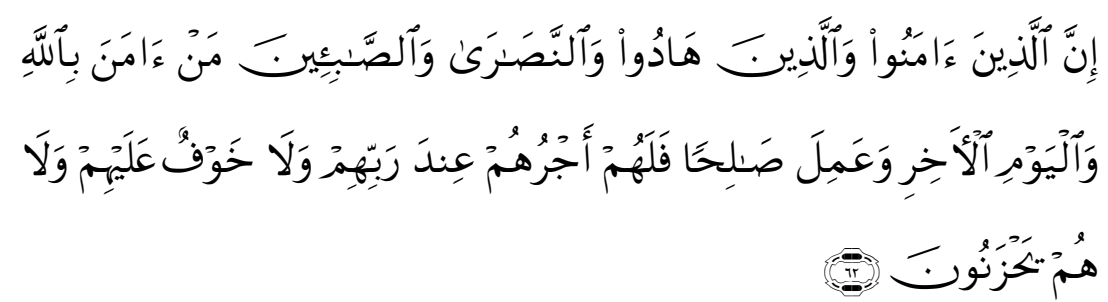

"Sesungguhnya orang-orang mukmin, orang-orang Yahudi, orang-orang Nasrani dan orang-orang Shabiin, siapa saja diantara mereka yang benarbenar beriman kepada Allah, hari kemudian dan beramal saleh, mereka 
akan menerima pahala dari Tuhan mereka, tidak ada kekhawatiran kepada mereka, dan tidak (pula) mereka bersedih hati" \{QS. Al-Baqarah [2]: 62].

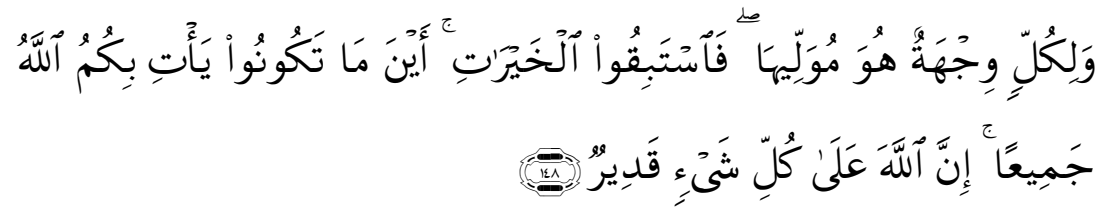

"Dan bagi tiap-tiap umat ada kiblatnya (sendiri) yang ia menghadap kepadanya. Maka berlomba-lombalah (dalam membuat) kebaikan. di mana saja kamu berada pasti Allah akan mengumpulkan kamu sekalian (pada hari kiamat). Sesungguhnya Allah Maha Kuasa atas segala sesuatu" \{QS. Al-Baqarah [2]: 148\}.

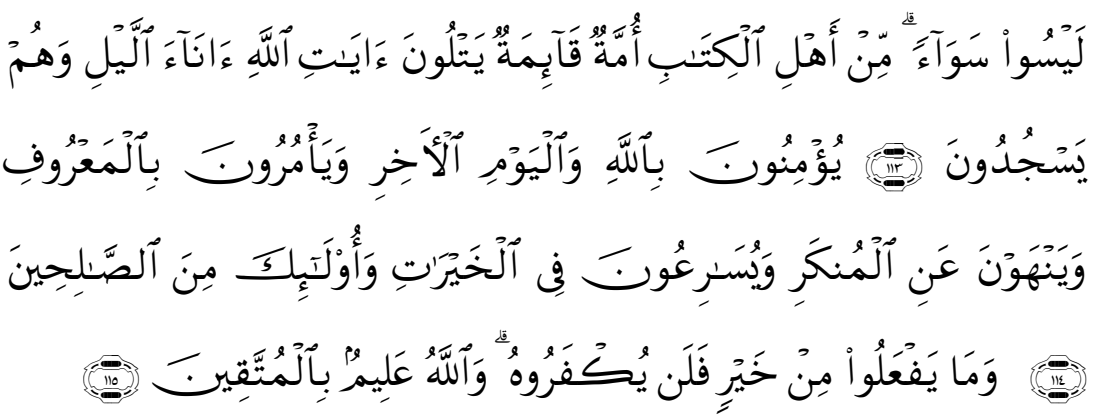
"Mereka itu tidak sama; di antara ahli kitab itu ada golongan yang berlaku lurus, mereka membaca ayat-ayat Allah pada beberapa waktu di malam hari, sedang mereka juga bersujud (sembahyang). Mereka beriman kepada Allah dan hari penghabisan, mereka menyuruh kepada yang ma'ruf, dan mencegah dari yang Munkar dan bersegera kepada (mengerjakan) pelbagai kebajikan; mereka itu Termasuk orang-orang yang 
saleh. Dan apa saja kebajikan yang mereka kerjakan, Maka sekali-kali mereka tidak dihalangi (menenerima pahala) nya; dan Allah Maha mengetahui orang-orang yang bertakwa" \{QS. Ali Imran [3]: 113-115\}.

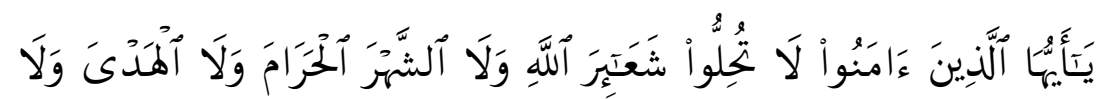

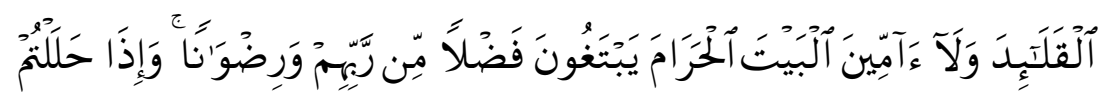

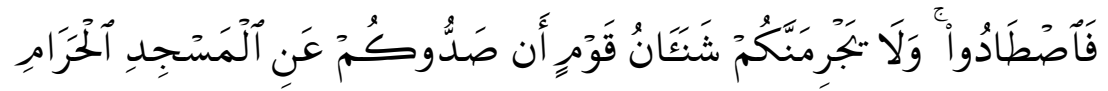

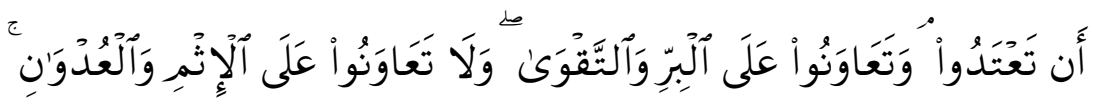

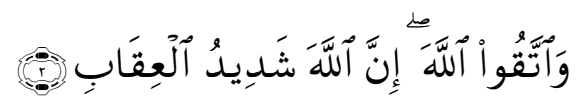

"Hai orang-orang yang beriman, janganlah kamu melanggar syi'ar-syi'ar Allah, dan jangan melanggar kehormatan bulan-bulan haram, jangan (mengganggu) binatang-binatang had-ya, dan binatang-binatang qalaa-id, dan jangan (pula) mengganggu orang-orang yang mengunjungi Baitullah sedang mereka mencari kurnia dan keredhaan dari Tuhannya dan apabila kamu telah menyelesaikan ibadah haji, Maka bolehlah berburu. dan janganlah sekali-kali kebencian(mu) kepada sesuatu kaum karena mereka menghalang-halangi kamu dari Masjidilharam, mendorongmu berbuat aniaya (kepada mereka). dan tolong-menolonglah kamu dalam (mengerjakan) kebajikan dan takwa, dan jangan tolong-menolong dalam berbuat dosa dan pelanggaran. dan bertakwalah kamu kepada Allah, Sesungguhnya Allah Amat berat siksa-Nya" \{QS. Al-Maidah [5]: 2\}. 
Keenam, konsep Islam dengan tegas dan jelas bahwa harus sering berdialog antar umat beragama untuk menambah dan memperkaya wawasan sehingga saling mengenal dan memahami. Di samping itu, dengan sering berdialog secara otomatis saling bertemu dan saling menyapa sehingga dapat mencairkan berbagai kebekuan masalah dan dapat diselesaikannya dengan cara yang baik dan menyenangkan.

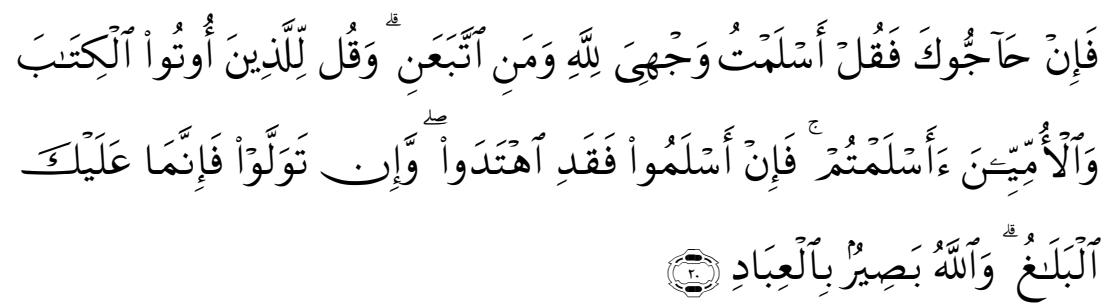

"Kemudian jika mereka mendebat kamu (tentang kebenaran Islam), Maka Katakanlah: "Aku menyerahkan diriku kepada Allah dan (demikian pula) orang-orang yang mengikutiku". dan Katakanlah kepada orang-orang yang telah diberi Al kitab dan kepada orang-orang yang ummi: "Apakah kamu (mau) masuk Islam". jika mereka masuk Islam, Sesungguhnya mereka telah mendapat petunjuk, dan jika mereka berpaling, Maka kewajiban kamu hanyalah menyampaikan (ayat-ayat Allah). dan Allah Maha melihat akan hamba-hamba-Nya" \{QS. Ali Imran [3]: 20\}. 


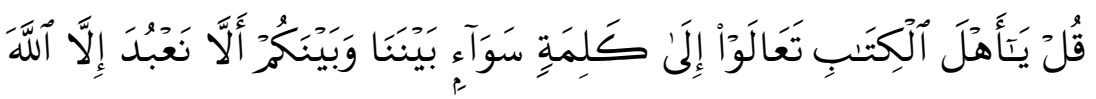

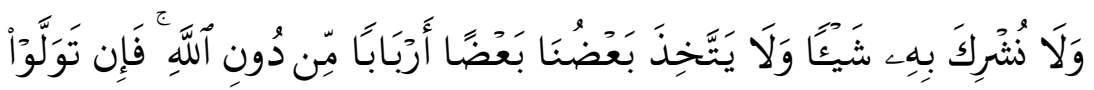

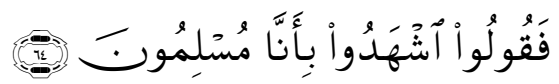

"Katakanlah: "Hai ahli Kitab, Marilah (berpegang) kepada suatu kalimat (ketetapan) yang tidak ada perselisihan antara Kami dan kamu, bahwa tidak kita sembah kecuali Allah dan tidak kita persekutukan Dia dengan sesuatupun dan tidak (pula) sebagian kita menjadikan sebagian yang lain sebagai Tuhan selain Allah". jika mereka berpaling Maka Katakanlah kepada mereka: "Saksikanlah, bahwa Kami adalah orangorang yang berserah diri (kepada Allah)" \{QS. Ali Imran [3]: 64\}.

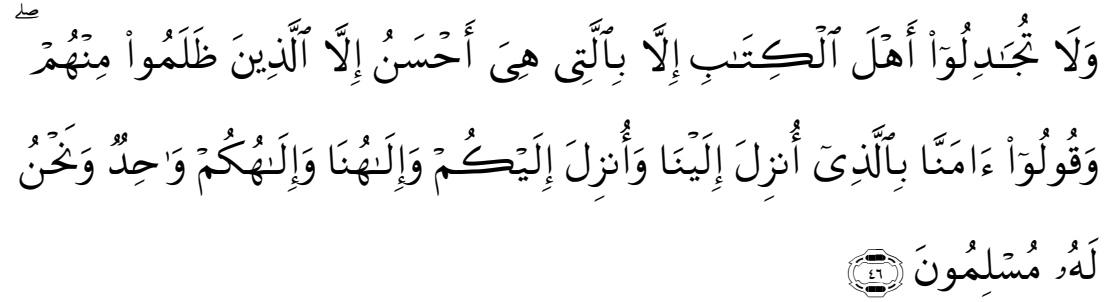

"Dan janganlah kamu berdebat denganAhli Kitab, melainkan dengan cara yang paling baik, kecuali dengan orang-orang zalim di antara mereka, dan Katakanlah: "Kami telah beriman kepada (kitab-kitab) yang diturunkan kepada Kami dan yang diturunkan kepadamu; Tuhan Kami dan Tuhanmu adalah satu; dan Kami hanya kepada-Nya berserah diri" \{QS. Al-Ankabut [29]: 46\}. 
Ketujuh, konsep Islam dengan tegas dan jelas bahwa mengakui. ada titik yang sama dan ada titik yang berbeda dalam agama-agama yang diturunkan Tuhan kepada manusia karena Tuhan menurunkan semua utusannya sama dalam mengajarkan tentang keyakinan kepada Tuhan, beribadah dan selalu menebarkan kebaikan, Oleh karena itu, setuju dalam kesamaan dan menghargai dalam perbedaannya.

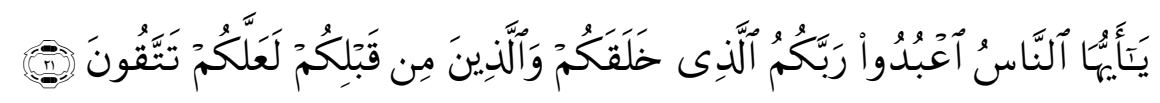

"Hai manusia, sembahlah Tuhanmu yang telah menciptakanmu dan orang-orang yang sebelummu, agar kamu bertakwa" \{QS. Al-Baqarah [2]: 21\}.

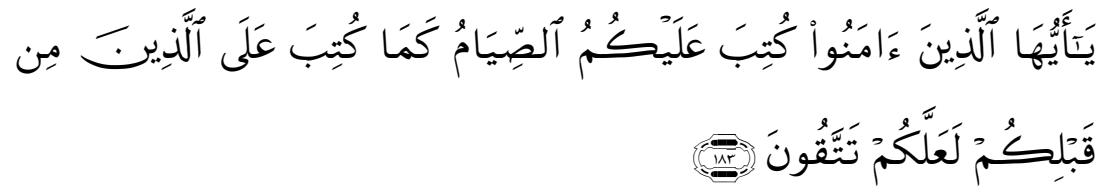

"Hai orang-orang yang beriman, diwajibkan atas kamu berpuasa sebagaimana diwajibkan atas orang-orang sebelum kamu agar kamu bertakwa" \{QS. Al-Baqarah [2]: 183\}.

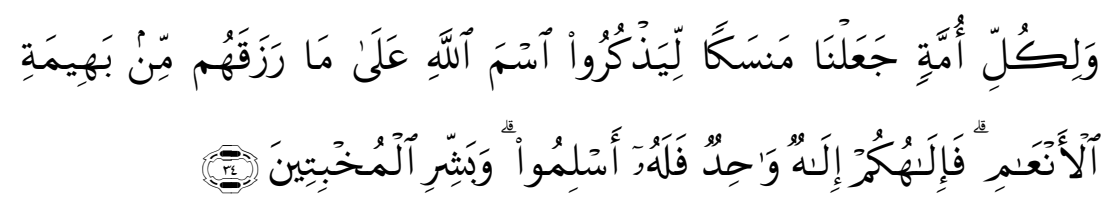

"Dan bagi tiap-tiap umat telah Kami syariatkan penyembelihan (kurban), supaya mereka menyebut nama Allah terhadap binatang ternak yang telah direzkikan Allah kepada mereka, Maka Tuhanmu ialah Tuhan 
yang Maha Esa, karena itu berserah dirilah kamu kepada-Nya. dan berilah kabar gembira kepada orang-orang yang tunduk patuh (kepada Allah)" \{QS. Al-Hajj [22]: 34\}.

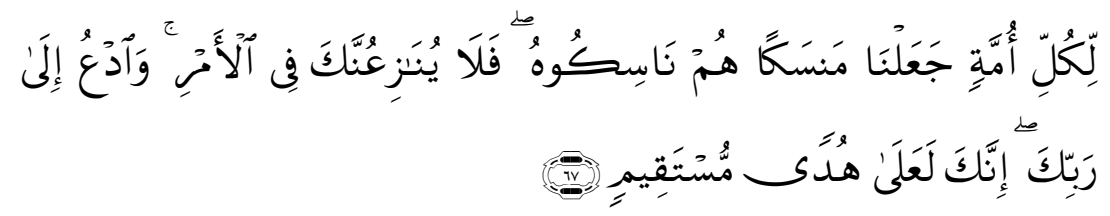

"Bagi tiap-tiap umat telah Kami tetapkan syari'at tertentu yang mereka lakukan, Maka janganlah sekali-kali mereka membantah kamu dalam urusan (syari'at) ini dan serulah kepada (agama) Tuhanmu. Sesungguhnya kamu benar-benar berada pada jalan yang lurus" \{QS. AlHajj [22]: 67\}.

Kedelapan, konsep Islam dengan tegas dan jelas bahwa harus komitmen dengan agama yang diyakini dan diimaninya sehingga dapat difahami oleh umat yang lain sehingga muncul saling menghargai dan menghormati serta tidak melecehkan atas kebenaran yang diyakininya. Allah menyatakan dalam firman-Nya:

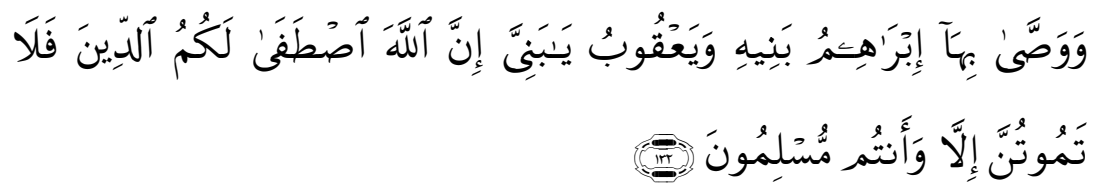

"Dan Ibrahim telah Mewasiatkan Ucapan itu kepada anak-anaknya, demikian pula Ya'qub. (Ibrahim berkata): "Hai anak-anakku! Sesungguhnya Allah telah memilih agama ini bagimu, Maka janganlah 
kamu mati kecuali dalam memeluk agama Islam" \{QS. Al-Baqarah [2]:
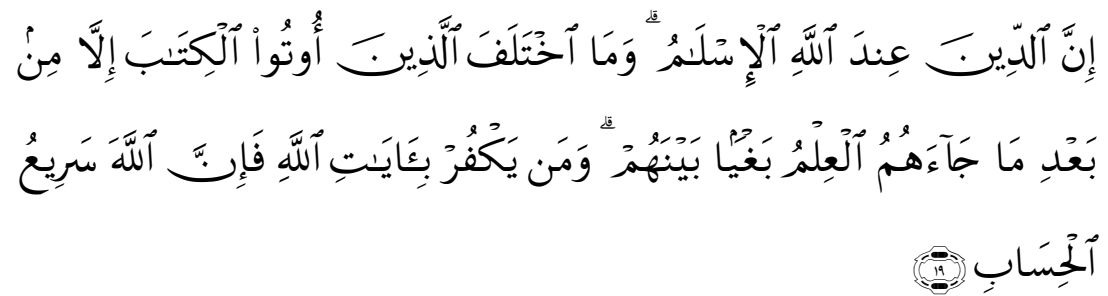

"Sesungguhnya agama (yang diridhai) disisi Allah hanyalah Islam. tiada berselisih orang-orang yang telah diberi Al-Kitab kecuali sesudah datang pengetahuan kepada mereka, karena kedengkian (yang ada) di antara mereka. Barangsiapa yang kafir terhadap ayat-ayat Allah Maka Sesungguhnya Allah sangat cepat hisab-Nya" \{QS. Ali Imran [3]: 19\}.

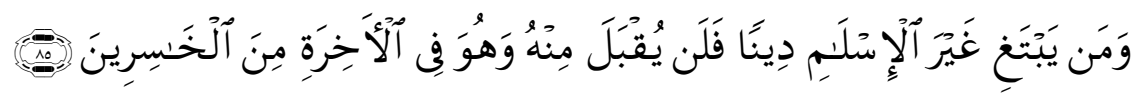

"Barangsiapa mencari agama selain agama Islam, Maka sekali-kali tidaklah akan diterima (agama itu)daripadanya, dan Dia di akhirat Termasuk orang-orang yang rugi" \{QS. Ali Imran [3]: 85\}.

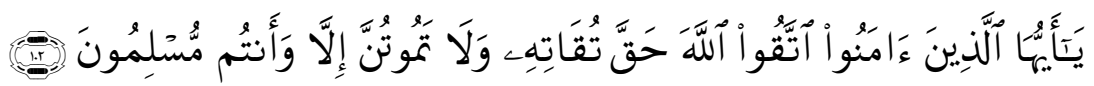

"Hai orang-orang yang beriman, bertakwalah kepada Allah sebenar-benar takwa kepada-Nya; dan janganlah sekali-kali kamu mati melainkan dalam Keadaan beragama Islam" \{QS. Ali Imran [3]: 102\}. 


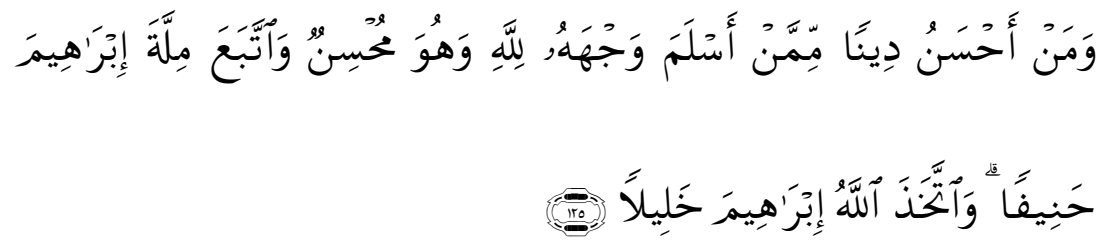

"Dan siapakah yang lebih baik agamanya dari pada orang yang ikhlas menyerahkan dirinya kepada Allah, sedang diapun mengerjakan kebaikan, dan ia mengikuti agama Ibrahim yang lurus? dan Allah mengambil Ibrahim menjadi kesayanganNya" \{QS. An-Nisa [4]: 125\}.

Kesembilan, konsep Islam dengan tegas dan jelas bahwa harus mencintai kedamaian dengan penuh kasih sayang, penuh keadilan, penuh kejujuran dan penuh persaudaraan. Bukan dengan kebencian, kezaliman dan permusuhan melainkan dengan kebenaran dan kasih sayang karena Islam adalah agama yang penuh rahmah dan perdamaian. Allah menyatakan dalam firman-Nya:

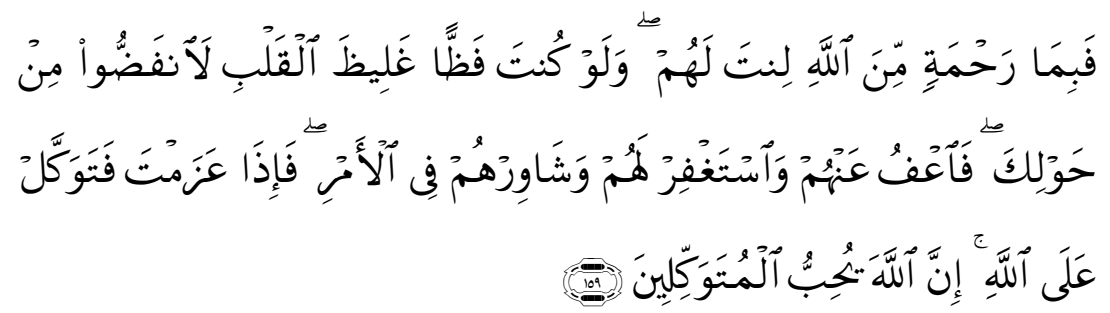

"Maka disebabkan rahmat dari Allah-lah kamu Berlaku lemah lembut terhadap mereka. Sekiranya kamu bersikap keras lagi berhati kasar, tentulah mereka menjauhkan diri dari sekelilingmu. karena itu ma'afkanlah mereka, mohonkanlah ampun bagi mereka, dan 
bermusyawaratlah dengan mereka dalam urusan itu. kemudian apabila kamu telah membulatkan tekad, Maka bertawakkallah kepada Allah. Sesungguhnya Allah menyukai orang-orang yang bertawakkal kepadaNya" \{QS. Ali Imran [3]: 159\}.

Kemudian Allah mengaskan dengan firman-Nya.

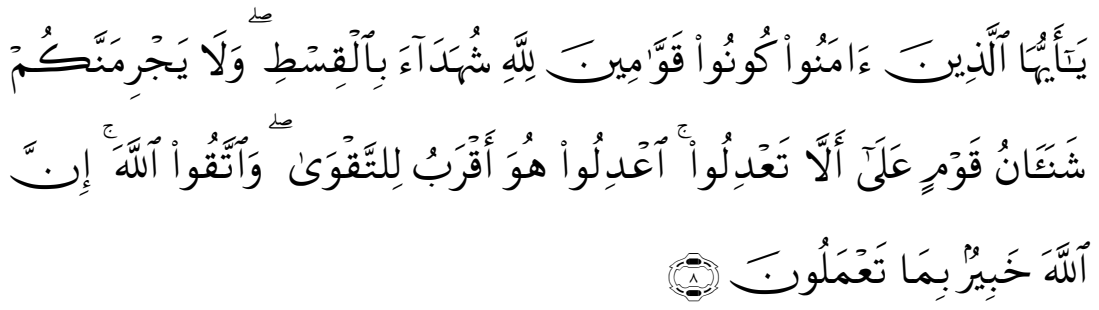

"Hai orang-orang yang beriman hendaklah kamu Jadi orang-orang yang selalu menegakkan (kebenaran) karena Allah, menjadi saksi dengan adil. dan janganlah sekali-kali kebencianmu terhadap sesuatu kaum, mendorong kamu untuk berlaku tidak adil. Berlaku adillah, karena adil itu lebih dekat kepada takwa. dan bertakwalah kepada Allah, Sesungguhnya Allah Maha mengetahui apa yang kamu kerjakan” \{QS. Al-Maidah [5]: 8\}.

Dari berbagai ayat tersebut di atas, menunjukkan bahwa Islam adalah agama yang sangat toleransi terhadap umat lain yang telah dicontohkan oleh Nabi Muhammad Saw. dan juga yang dilakukan oleh khalafaturrosyidin hingga hari ini. Dalam kaitan ini, Syaikh Salim bin "Ied Al-Hilali menyatakan bahwa toleransi dalam Islam lebih dalam nilai kandungannya daripada mafhum kemanusiaan masa kini, karena 
toleransi ini menembus penampilan dhahir dan yang kasat mata sampai dasar lubuk hati yang paling dalam. Toleransi dalam Islam lebih kekal dari mafhum kemanusiaan masa kini yang akan habis dengan punahnya jenis manusia di muka bumi ini, karena toleransi ini akan menyambungkan seorang muslim dengan kehidupan akhiratnya. ${ }^{5}$ Begitu pula, Yunus Ali Muhdhar menyatakan bahwa dapat kita saksikan dengan jelas dalam sejarah berkembangan Islam yang tidak pernah disiarkan dengan paksaan atau dengan tipu muslihat, baik sejak zaman Nabi Muhammad Saw. maupun sampai masa kini. Bahkan penyiarannya selalu diikuti dengan penuh toleransi dan cara yang luwes untuk mengajak ke dalam agama Islam. Islam dengan cepat tersiar di penjuru dunia karena Islam selaras ajarannya dengan fitrah manusia, cocok dengan segala zaman dan tempat. $^{6}$

Memang benar, bahwa Islam adalah agama yang mendukung tegaknya kerukunan atau toleransi. Hal ini, terbukti di Indonesia yang masyarakatnya adalah rukun dan dapat hidup berdampingan dan damai dengan umat-umat lain. Bahkan Moazzam Malik Duta Besar Inggris di Indonesia mengakui bahwa cara beragama umat Islam di Indonesia bisa menjadi contoh dan dipelajari oleh umat Islam di negara lain, termasuk

5 Syaikh Salim bin "ied Al-Hilali, Toleransi Islam Menurut Pandangan Al-Qur'an dan As-Sunnah, \{Tegal: Maktabah Salafy Press, 2001\}, cet. ke-1, hlm. 11

6 Yunus Ali Muhdhar, Toleransi Kaum Muslimin dan Sikap Musuh-musuhnya, \{Surabaya: Bungul Indah, 1994\}, cet. ke-1, hlm. 5 
umat Islam di Inggris, Eropa, bahkan umat Islam di seluruh dunia. Indonesia berbeda dengan negara muslim lainnya, negeri ini lebih moderat, plural dan umat beragamanya memiliki tingkat toleransi yang tinggi. $^{7}$

Begitu pula, Raja Arab Saudi, Salman bin Abdul Aziz al-Saud mengapresiasi toleransi di Indonesia dalam pertemuan dengan tokoh lintas agama, bahwa toleransi menjadi modal kuat untuk kemajuan bersama. ${ }^{8}$ Bahkan Presiden Prancis, Francois Hollande memuji kemampuan Indonesia sebagai Negara berpenduduk muslim terbesar di dunia menjaga nilai-nilai toleransi dengan baik di tengah keberagaman atau kebenekaan Indonesia, yakni menjunjung tinggi kebebasan dan nilainilai toleransi. Melalui konsepsi Islam yang dimiliki Indonesia sebagai suatu cara untuk hidup bersama-sama. ${ }^{9}$ Bahkan Duta Besar Amerika, Josept R. Donovan menyampaikan penghargaan atas tingginya toleransi rakyat Indonesia terhadap keragaman dan juga mengapresiasi Islam di Indonesia sebagai Islam yang moderat dan modern. ${ }^{10}$

${ }^{7}$ Republika, “Cara Beragama Muslim Indonesia Patut Dicontoh” [Jakarta, 29 Februari, 2016], hlm. 12

${ }^{8}$ Media Indonesia, "Toleransi di Indonesia Kian Diakui Dunia” [Jakarta: 31 Maret 2017], hlm. 2

9 Media Indonesia, "Hollande Puji Toleransi Indonesia", [Jakarta: 30 Maret 2017], hlm. 1

${ }^{10}$ Media Indonesia, "Toleransi di Indoensai Kian Diakui Dunia” 
2. Konsep Kerukunan Kristen

Kristen [Katolik dan Protestan] adalah agama yang datang di Indonesia melalui kolonialis Belanda maupun Protugis sehingga perkembangan agama ini, menjadi benturan dengan agama-agama yang lain karena agama Kristen mengembangkan misinya dengan cara yang tidak fair yang dikenal dengan cara kristenisasi yang ditunjukkan kepada agama lain [Matius, 28: 18-20, Markus, 16: 14-16, Kisah Rasul-rasul, 1: 68]. Dengan cara ini. menimbulkan konflik dengan agama-agama yang ada di Indonesia, terutama dengan umat Islam. Kalau para missi Kristen menggunakan Injil Matius, 10: 5-9 ini, maka tidak akan menimbulkan gesekan dengan agama-agama lain dan bisa hidup dengan rukun:

Pertama, Yesus Kristus menyebarkan agama Allah kepada Bani Israel yang sesat bukan kepada kaum Muslim, Hindu, Buddha dan Konghucu melainkan seharusnya kepada kaum Kristen agar lebih kuat keimanan dan keyakinan kepada Tuhan Yang Maha Kuasa. Bahkan Yesus Kristus telah memberikan suatu contoh yang baik tentang kerukunan atau toleransi yang harus diaplikasikan dalam kehidupan beragama di Indonesia . Sebagaimana dinyatakan dalam Kitab Injil Matius sebagai berikut:

"Kedua belas rasul itu kemudian diutus oleh Yesus dengan mendapat petunjuk-petunjuk ini. Janganlah pergi ke daerah orang-orang bukan 
Yahudi. Jangan juga ke kota-kota Samaria. Tetapi pergilah kepada orangorang Israel, khususnya kepada mereka yang sesat. Beritahukanlah kepada mereka bahwa Allah akan segera memerintah sebagai Raja. Sembuhkanlah orang-orang sakit, hidupkanlah orang-orang yang mati, sembuhkan orang-orang yang berpenyakit kulit yang mengerikan, dan usirlah roh-roh jahat. Kalian sudah menerima semuanya itu dengan cuma-cuma. Jadi, berilah juga dengan Cuma-cuma. Jangan membawa uang emas, uang perak, ataupun uang tembaga" [Matius, 10-5-9].

"Yesus tidak menjawab wanita itu sama sekali. Lalu pengikut-pengikut Yesus datang kepadanya dan memohon. Pak, suruh wanita itu pergi. Dia hanya ribut-ribut saja di belakang kita. Yesus menjawab, Aku diutus hanya kepada bangsa Israel, khususnya kepada mereka yang sesat" [Matius, 15: 23-24].

Kedua, konsep Kristen tentang kebahagian dan perdamaian yang diajarkan oleh Yesus Kristus kepada kaumnya supaya hidup damai dan rukun. Hal ini, banyak diungkapkan dalam Kitab Injil sebagai berikut: "Berbahagialah orang-orang yang lembut karena mereka akan memiliki bumi. Berbahagialah orang-orang yang lapar dan haus akan kebenaran karena mereka akan dipuaskan. Berbahagilah orang yang murah hatinya karena mereka akan beroleh kemurahan. Berbahagilah orang yang suci hatinya karena mereka akan melihat Allah. Berbahgialah orang yang 
membawa damai karena mereka akan disebut anak-anak Allah" [Matius, 5: 5-9].

Ketiga, konsep Kristen tentang hukum cinta kasih kepada Allah dan kepada sesama manusia merupakan hukum utama yang harus ditegakkan dalam kehidupan orang Kristen .

"Jawab Yesus kepadanya, Kasihilah Tuhan, Allahmu, dengan segenap jiwamu dan segenap akal budimu. Itulah hukum yang terutama dan yang pertama. Dan hukum yang kedua, yang sama dengan itu, ialah kasihilah sesamamu manusia seperti dirimu sendiri" [Matius, 22: 37-40].

"Kasih tidak berbuat jahat terhadap sesame manusia karena itu kasih adalah kegenapan hukum taurat. Hal ini harus kamu lakukan..." [Roma, 13: 10].

"Kasih itu sabar, kasih itu murah hati, ia tidak cemburu. Ia tidak memegahkan diri dari dan tidak sombong. Ia tidak melakukan yang tidak sopan dan tidak mencari keuntungan diri sendiri. Ia tidak pemarah dan tidak menyimpan kesalahan orang lain. Ia tidak bersukacita karena ketidakadilan, tetapi ia bersukacita karena kebenaran" [I Korintus, 13: 4-6]

Ayat-ayat tersebut, merupakan konsep dasar kerukunan yang dijadikan acuan oleh Kristen Protestan dan Katolik yang sama-sama berasal dari Yesus Kristus. Akan tetapi, dalam masalah kerukunan atau toleransi, keduanya mempunyai pandangan yang berbeda. Keyakinan 
agama Kristen Protestan merupakan perintah utama dalam melaksanakan kehendak Tuhan dan setiap umat Kristen mempunyai tugas untuk mencari dan mengusahan perdamaian. Karena dalam ajaran Kristen diajarkan hidup rukun yang terdapat dalam Alkitab, yaitu hukum kasih dan hukum kasih bagi Kristen adalah hukum utama dalam kehidupan orang Kristen Protestan. ${ }^{11}$

Sedangkan dalam ajaran Katolik bahwa toleransi suatu bentuk antar umat beragama yang terkandung dalam Konsili Vatikan II tentang sikap gereja terhadap agama lain. Dalam Mukadimah Konsili Vatikan tersebut "Dalam zaman kita ini di mana bangsa manusia makin hari makin erat bersatu, hubungan antar bangsa menjadi kokoh, Gereja lebih seksama mempertimbangkan bagaimana hubungannya dengan agama-agama Kristen lainnya karena tugasnya memelihara persatuan dan perdamaian di antara manusia dan juga di antara hidup berbangsa". ${ }^{12}$

3. Konsep Kerukunan Hindu

Agama Hindu adalah agama yang pertama kali datang di Indonesia melalui para Raja dan agama ini mempunyai pandangan tentang kerukunan hidup atau toleransi antarumar beragama dapat

11 Badan Penelitian dan Pengembangan Ham Departeman Hukum dan Ham, Evaluasi Pengaruh Kondisi Terhadap Toleransi Beragama di Indonesia, [Jakarta, 2009], hlm. 46, lihat juga, Bashori Mulyono, Ilmu Perbandingan Agama, \{Indramayu: Pustaka Sayid Sabiq, 2010\}, cet. ke-1, hlm. 125

${ }^{12}$ Badan Penelitian dan Pengembangan Ham Departeman Hukum dan Ham, op.cit, hlm. 47 


\section{6 | Syafi'in Mansur}

diketahui dari tujuan agama Hindu adalah "Moksartham Jagathita Ya ca iti Dharma" yang artinya mencapai kesejahteraan hidup manusia baik jasmani maupun rohani. Dari pengertian tersebut, maka untuk mencapai kerukunan umat beragama manusia harus mempunyai dasar hidup yang disebut "Catur Purusa Artha". Yakni Dharma Artha, Kama dan Moksa. Hal itu dapat dijelaskan sebagai berikut:

1. Dharma, berarti susila dan berbudi luhur. Dengan Dharma pula seseorang dapat mencapai kesempurnaan hidup, baik untuk diri, keluarga dan masyarakat [umat manusia]. Apabila dharma ini telah terwujud, maka tujuan hidup lainnya seperti Artha, Kama dan Moksha akan dialami pula,

2. Artha berarti kekayaan, dapat memberikan kenikmatan dan kepuasan hidup, serta cara mencapainya harus dilandasi dharma.

3. Kama, bermakna kenikmatan dan kepuasan, seperti kesenian dapat memuaskan orang, Kama dapat pula dipuaskan oleh artha, sehingga dalam mencari artha dan pemakaiannya harus berdasarkan dharma. Oleh karena itu, jika orang ingin mencari kama dan artha terlebih dahulu harus melaksanakan dharma dan tidak boleh menyimpang dari dharma.

4. Moksha adalah merupakan kebahagian abadi, yakni berlepasnya atman [jiwa] dari lingkaran sanfara atau bersatunya kembali atman dengan paramatma dan moksha menjadi tujuan terakhir dari agama 
Hindu yang setiap saat dicari sampai berhasil. Mencapai moksha dasarnya juga dharma, Jadi hanya dharmalah yang dapat dipakai sebagai wahana untuk sampai kepada moksha. ${ }^{13}$

Dari dasar tersebut, toleransi merupakan kerukunan hidup antar umat beragama yang mempunyai landasan hidup harmonis saling kasih sayang dan adanya pandangan asah, asih dan asuh. Dasar yang lain adalah statemen dari Kitab Regweda yang berbunyi "Ekan Sat Vipra Bahuda Vadanti" yang mempunyai arti "Disebut dengan ribuan nama berbeda, namun satu adanya”. Tidak berbeda dengan semboyan Bkinneka Tunggal Ika yang menjadi jargon bangsa Indonesia. Jargon tersebut, diambil oleh Mpu Tantular dari konsep teologi Hindu yang berbunyi "Bhina ika tunggal $i k a$, tan hana dharma mengrwa". Artinya berbeda-beda tetap tetap satu juga, tidak ada ajaran yan menduakan. Maksudnya adalah jalan menuju Tuhan bisa berbeda tetapi yang dituju satu adanya dan tidak ada ajaran yang menduakannya. $^{14}$

4. Konsep Kerukunan Buddha

Agama Buddha adalah berkembangan dari agama Hindu yang ada di India dan juga berkembang di Indoensia yang dibawa oleh para Raja. Agama Buddha ini, mempunyai pandangan tentang kerukunan hidup

\footnotetext{
${ }^{13}$ Bashori Mulyono, op.cit, hlm. 121-122

${ }^{14}$ Badan Penelitian dan Pengembangan Ham Departeman Hukum dan Ham, op.cit, hlm. 48-49
} 
Bergama yang berdasarkan empat kebenaran, yakni dhuha satya , samudaya satya, tanha dan marga satya. Dari dasar ini, maka pelayanan Buddha Gautama terhadap manusia berarti telah dilaksanakan dengan dasar sebagai berikut adalah [1] Keyakinan Tuhan Yang Maha Esa tidak dapat ditembus oleh pikiran manusia, [2] Metta, welas asih yang menyeluruh terhadap semua makhluk, sebagai kasih ibu terhadap putranya yang tunggal, [3] Karunia, kasih sayang terhadap sesama makhluk dan kencendrungan untuk selalu meringankan penderitaan makhluk lain, [4] Mudita, perasaan turut bahagia dengan kebahgian makhluk lain tanpa benci, iri hati dan perasaan prihatin bila makhluk lain menderita, [5] Karma, reinkarnasi atau hukum umum yang kekal, karena ini adalah hukum sebab akibat. Oleh karena itu, karma adalah jumlah keseluruhan dari perbuatan-perbuatan baik dan tidak baik. ${ }^{15}$

Dari dasar tersebut, keyakinan menurut umat agama Buddha bahwa toleransi adalah kerukunan hidup beragama dapat dicapai dengan bertilik tolak kepada knsep dharma. Dalam dharma ini diajarkan bagaimana cara melaksanakan perbuatan baik, bagaimana cara menghindarkan perbuatan jahat, mengajar cinta kasih dan menumbuhkan sikap toleransi dan partisipasi, rukun antar umat beragama. Bahkan bukti sejarah ajaran toleransi Budha ini bisa dilihat

${ }^{15}$ Bashori Mulyono, op.cit, hlm. 123-124

Aqlania, Vol. 08, No. 02 (Juli-Desember) 2017 ISSN: 2087-8613 
dalam prasti dalam Batu Lingga XXII Raja Asoka [abad III SM] antara lain disebutkan bahwa umat Budha tidak boleh mencela agama orang lain tanpa dasar yang kuat. Sebaliknya umat Budha diperintahkan untuk memberikan penghormatan kepada agama lain sehingga secara tidak langsung akan membantu agama Budha berkembang. ${ }^{16}$

5. Konsep Kerukunan Konghucu

Agama Khonghucu termasuk agama yang baru diterima oleh bangsa Indonesia. Agama ini mengajarkan tentang toleransi yang sebenarnya yang menjadi prinsip dasar dari ajaran Khongucu adalah "Jangan lalukan [kepada orang lain] apa yang tidak ingin engkau terima diperlakukan oleh orang lain" [Tengah Sempurna, XII: 3]. Di samping itu, Nabi Khonghucu menyatakan bahwa "Seorang budiman berhati longgar dan lapang, seorang rendah budi berhati sempit dan berbelit-belit" [Sabda Suci, VII: 37].

Kemudian Nabi Khonghucu menegaskan dengan sabdanya "Seorang budiman menjunjung tiga syarat di dalam jalan suci. Di dalam sikap dan lakunya, ia menjauhkan sikap congkak dan angkuh, pada wajahnya selalu menunjukkan sikap dapat dipercaya dan di dalam percakapan selalu ramah serta

${ }^{16}$ Badan Penelitian dan Pengembangan Ham Departeman Hukum dan Ham, op.cit, hlm. $47-48$ 
menjauhi kata-kata kasar" [Sabda Suci, VIII: 43]. Dan "di tempat penjuru lautan, semuanya bersaudara" [Sabda Suci, XII: 5]. ${ }^{17}$

C. Aplikasi Kerukunan Dalam Kehidupan Umat Beragama di Indonesia

Berdasarkan kitab suci umat beragama tersebut di atas, maka jelas dan terang bahwa semua kitab suci mendukung tegaknya kerukunan interen umat beragama, kerukunan antarumat beragama, dan kerukunan antara umat beragama dengan pemerintah. Bahkan Ap. Biyono HD menyatakan bahwa kalau kita sungguh-sungguh taat pada ajaran agamanya masing-masing sebagaimana diajarkan dalam kitab sucinya. Sebetulnya tidak sulit, sebab setiap agama pasti mengajarkan penganutnya untuk hidup rukun baik terhadap sesama umat beragama maupun terhadap semua umat beragama. ${ }^{18}$

Memang benar, kalau kita memahami secara seksama isi kandungan kitab suci kita masing-msing, maka secara otomatis kerukunan itu akan menjelma dalam kehidupa umat beragama. Tetapi sebaliknya, jika kita tidak dapat memahami secara baik dan benar isi kandungan kitab suci kita masing-amsing, maka secara otomatis akan menimpulkan ketidak rukunan dan menimbulkan konflik serta salah faham sehingga

${ }^{17}$ Ibid, hlm. 49-50

18 Ap. Budiyono HD, Membina Kerukunan Hidup Antar Umat Beriman, \{Yogyakarta: Kanisius, 1983\}, cet. ke-1, jld. 2, hlm. 284

Aqlania, Vol. 08, No. 02 (Juli-Desember) 2017 ISSN: 2087-8613 
memunculkan ketidak toleransian dalam beragama. Dalam persoalan ini, wajar para tokoh agama dan intelektual menganggap bahwa kerukunan itu sudah usang dan membosankan hingga perlu diganti namanya bukan kerukunan umat beragama karena tidak dapat menyelesaikan persoalan hingga kini. Bahkan Nurcholish Madjid menyatakan bahwa ungkapan "kerukunan agama" terasa seperti agak usang, boleh dikata, tiap hari orang membincangkannya, baik kalangan umum maupun para pejabat. Perbincangan tentang kerukunan agama hampir-hampir membosankan, bagaikan jalan yang banyak ditempuh. ${ }^{19}$ Begitu pula, Abd. Rohim Ghazali menegaskan bahwa tema klasik kerukunan antar umat beragama agaknya akan menjadi agenda nasional yang tak kunjung usai. Ini harus dipandang karan adanya disintegrasi yang menjadi momok bagi bangsa kita yang majemuk dan biasanya terpicu gara-gara kesalahpahaman antar umat beragama. $^{20}$

Berbagai pandangan tersebut, dikuatkan pula oleh Kuntowijoyo bahwa kerukunan atau tolerasnsi digantikan dengan kerja sama atau koopersi. Di masa depan, yang kita perlukan bukan kerukunan atau toleransi, tetapi kerja sama atau kooperasi antarumat beragama. Untuk keperluan itu, umat beragama yang sebenarnya berada dalam front yang

${ }^{19}$ Andito, [Edt.], Atas Nama Agama Wacana Agama dalam Dialog Bebas Konflik, \{Bandung: Pustaka Hidayah, 1998\}, cet. ke-1, hlm. 177

${ }^{20}$ Ibid, hlm. 327 
sama, dapat membuat agenda bersama, yakni agenda nasional seperti masalah pembangunan, keadilan, kemiskinan, keterbelakangan dan agenda global seperti tangtangan modernitas, aliensai, spiritualisme, dan nilai-nilai kemanusiaan pada umumnya. ${ }^{21}$ Walau bagaimana pun, kerukunan telah memberikan kontribusi kepada para tokoh agama, para ilmuwan, para penjabat dan masyarakat yang telah diperjuangkan untuk menjadi rukun dan damai di Republik Indonesia. Sebagaimana yang dipesankan oleh Presiden RI bahwa mengingat kemajemukan bangsa kita, maka saya dengan tidak jemu-jemunya mengingatkan agar kita semua, terutama para pemimpin bangsa kita, lebih-lebih para pemuka agama, untuk memelihara kerukunan di antara kita. ${ }^{22}$ Berarti kerukunan umat beragama memang harus diperjuangkan karena tidak lepas dari intrikintrik yang tidak senang terhadap kedamaian, ketenangan dan hidup rukun di bangsa Indonesia. Maka para Menteri Agama telah membuat tahap-tahap perkembangan dan tantangan benbangunan sehingga kerukunan itu tetap hidup di bangsa Indonesia, antara lain:

1. Pada saat Menteri Agama dijabat oleh Prof. Dr. H.A. Mukti Ali, secara filosofis dan konsepsional ditanamkan agree with disagree, setuju dalam perbedaan karena kenyataan bangsa

\footnotetext{
${ }^{21}$ Ibid, hlm. 359

${ }^{22}$ Ibid, hlm. 328
} 
kita adalah masyarakat yang mejemuk dalam agama yang dianutnya.

2. Pada masa Menteri Agama dijabat oleh Letjen TNI H. Alamsjah Ratu Perwiranegara digariskan tentang betapa pentingnya tiga kerukunan, yaitu kerukunan intern umat beragama, kerukunan antarumat beragama, dan kerukunan antara umat beragama dengan pemerintah.

3. Pada masa Menteri Agama dijabat oleh H. Munawir Sjadzali, MA lebih memantapkan semangat tiga kerukunan tersebut, dan dikembangkan semangat kemitraan sehingga umat beragama secara bersama-sama bertanggung jawab untuk meletakkan landasan spiritual, moral dan etik dalam pembangunan nasional dan mempunyai tekad untuk menyukseskan pembangunan nasional, termasuk sosial politik.

4. Pada masa Menteri Agama dijabat oleh Dr. H. Tarmizi Taher membentuk Lembaga Pengkajian Kerukunan Umat Beragama [LPKUB] dengan bingkai teologis dan cultural serta peningkatan kualitas Imtaq dan Imtek umat, umat beragama 
akan memberikan kontribusi dan peran serta yang lebih besar bagi Kebangkitan Nasional II ${ }^{23}$

Termasuk Menteri Agama yang lain pun, telah mengusung pula tegaknya kerukuan di Republik Indonesia. Dalam kaitan ini, Suparman Usman menyatakan bahwa kerukunan hidup umat beragama di Indonesia telah diusahakan dan berjalan dengan baik, tentu kewajiban kita bersama untuk terus membinanya kearah yang lebih baik dan mantap sehingga timbul rasa dan wujud persaudaraan dan persatuan antarumat beragama. Sehubungan dengan itu, maka upaya pembinaan kerukunan hidup beragama di Indonesia, baik kerukunan intern umat beragama maupun kerukunan antarumat beragama dan kerukunan antara umat beragama dengan pemerintah, dapat ditempuh melalui langkah-langkah sebagai berikut:

1. Masing-masing pemeluk agama agar mempelajari, memahami dan mengamalkan ajaran agamanya masing-masing dengan benar. Hal ini sangatlah penting karena kadang-kadang ada penganut suatu agama yang kurang memahami dan belum mengamalkan ajaran agamanya secara benar.

2. Setiap umat beragama agar selalu mentaati berbagai kesepakatan peraturan dan berbagai perundang-undangan yang berlaku, baik

${ }^{23}$ Majles Ulama Indonesia, Kerukunan Beragama dari Perspektif Negara, Ham dan Agama-agama, \{Jakarta: MUI, 1996\}, cet. ke-1, hlm. Xii-xiii 
peraturan tingkat pusat maupun peraturan daerah, sebagai ramburambu yang akan mengamankan lalu lintas kehidupan beragama, berkaitan dengan kerukunan yang ingin diciptakan oleh kita bersama.

3. Dialog baik insidentil maupun berkala, formal maupun informal, antara intern umat beragama, antarumat beragama dan antara umat beragama dengan pemerintah perlu terus ditingkatkan. Dialog itu harus dilandasai oleh niat dan sikap yang tulus, untuk menciptakan kerukunan hidup beragama baik secara nasional maupun regional dan lokal.

4. Masing-masing pihak, baik penganut agama maupun pemerintah agar selalu hati-hati dalam berucap dan bertindak. Masing-masing pihak jangan berperilaku yang dapat memancing emosi dan kecemburuan pihak lain, sehingga dapat menimbulkan kesalahpahaman, kecurigaan atau ketegangan di antara mereka. Sikap tenggang rasa, saling menghargai dan tidak bersangka buruk, perlu terus dikembangkan.

5. Mengadakan kegiatan bersama secara nyata yang dilakukan oleh semua penganut agama, yang memanfaatkannya dirasakan langsung oleh masyarakat. Kegiatan ini perlu direncanakan secara matang dan hati-hati, agar tidak menimbulkan kesalahpahaman dalam pelaksanaannya. 
6. Menghimpun dan menggalang generasi muda antarumat beragama, dalam wadah kerjasama sosial kemasyarakatan untuk menumbuhkan rasa persatuan persaudaraan sehingga dapat membuahkan kerjasama yang nyata di antara mereka, bagi terciptanya kerukunan hidup beragama.

7. Semua umat beragama agar selalu waspada dan hati-hati terhadap kemungkinan adanya provokasi dan hasutan dari pihak-pihak tertentu yang ingin mengadu domba dan memecah belah kerukunan hidup beragama. Masing-masing umat beragama saling memberikan informasi, apabila ada indikasi yang mengarah kepada usaha adu domba dan menghasut kerukunan hidup umat beragama tersebut.

8. Suatu kenyataan yang tidak dapat dipungkiri, bahwa memang terdapat berbagai perbedaan dalam kehidupan umat manusia umpamanya adanya pemeluk agama yang berbeda. Kenyataan adanya perbedaan ini tidak harus membawa perpecahan dan permusuhan di antara umat manusia karena suatu kenyataan pula bahwa di antara kita yang berbeda itu ada rasa saling membutuhkan untuk memenuhi kehidupan kita bersama. Pola yang perlu dikembangkan sebagaimana yang diungkapkan oleh M. Mukti Ali adalah kita harus bisa "bersatu dalam perbedaan” atau kita setuju dalam perbedaan. Ungkapan lain, diungkapkan oleh Syafi'i Ma'arif bahwa kita harus bersaudara dalam perbedaan dan bisa berbeda dalam persaudaraan. 
9. Setiap umat beragama harus menyadari bahwa kita semua berada dalam masyarakat plural [beraneka ragam] terdiri atas bermacammacam pemeluk agama baik dalam wadah satu Negara maupun dalam desa deunia [glabal village]. Oleh karena itu, baik secara perorangan tiap pemeluk agama maupun secara kelembagaan seperti Majlis Ulama Indonesia [MUI], Persekutuan Gereja-Gereja Indonesia [PGI], Konferensi Wali Gereja Indonesia [KWI], Parishada Hindu Dharma Indonesia [PHDI], Perwakilan Umat Buddha Indonesia [WALUBI], Majelis Tinggi Agama Konghucu [MATAKIN], mereka harus mempunyai sense of belonging dan sense of responsibility untuk memelihara, membina serta menyelesaikan konflik-konflik [kalau ada] di antara umat bersama.

10. Pemerintah yang mempunyai anggaran dan berbagai fasilitas yang dimilikinya harus selalu secara proaktif memfasilitasi lembagalembaga keagamaan dan Sekretariat Bersama Kerukunan Umat Beragama untuk melakukan kegiatan-kegiatan dalam rangka memelihara, membina dan meningkatkan kerukunan hidup umat beragama. $^{24}$

24 Suparman Usman, "Kemajemukan dan Kerukunan Umat Beragama Tinjauan Singkat Kemajemukan dan Kerukunan Menurut Islam dan Perundangundangan di Indonesia”, [Makalah, Serang, 2007], hlm. 22-23 
Dari sepuluh upaya untuk membina kerukunan hidup umat beragama tersebut, dikuatkan dan dikongkritkan lagi yang diungkapkan oleh Harun Nasution bahwa ada berapa yang dapat dipupuk dengan jiwa toleransi ini, antara lain: [1] Mencoba melihat kebenaran yang ada dalam agama lain, [2] Memperkecil perbedaan yang ada dalam agama-agama, [3] Menonjolkan persamaan-persamaan yang ada dalam agama-agama, [4] Memupuk rasa persaudaraan se-Tuhan, [5] Memusatkan usaha pada pembinaan individu-individu dan masyasarakat manusia baik yang menjadi tujuan beragama dari agama monoteis, [6] Mengutamakan pelaksanaan ajaran-ajaran yang membawa kepada toleransi beragama, [7] Menjauhi praktek serang-menyerang antar agama. ${ }^{25}$ Dari semua paparan tersebut, kuncinya adalah toleransi atau kerukunan yang ditegakkan dengan hati yang tulus dan niat yang baik maka akan menghasilkan kedamaian, ketentaraman dan kerukuan antar umat beragama di Indonesia sesuai dengan konsepsi ajaran agama yang mendukung tegaknya pilar kerukunan atau toleransi di Indonesia.

\section{Penutup}

Dalam bagian penutup ini, dapat ditegaskan bahwa kerukunan atau toleransi umat beragama di Indonesia ini sudah sangat baik karena

25 Harun Nasution, Islam Rasional Gagasan dan Pemikiran, \{Bandung: Mizan, 1996\}, cet. ke-4, hlm. 275

Aqlania, Vol. 08, No. 02 (Juli-Desember) 2017 ISSN: 2087-8613 
semua agama sama-sama menjaga umatnya untuk menjadi rukun, damai, kasih sayang dan saling menghormati dan menghargai. Bahkan Indonesia bisa menjadi contoh bagi dunia tentang toleransi atau kerukunan yang dapat tumbuh dengan keragamaan atau khebinekaan. Begitu pula, para tokoh agama saling bahu-membahu dalam menciptakan kerukunan atau toleransi yang didukung kuat oleh para ulama dan kiai serta para mubaligh Islam. 


\section{DAFTAR PUSTAKA}

Sudirman Tebba, Islam Pasca Orde Baru, \{Yogyakarta: Tiara Wacana Yogya, 2001\}, cet. ke-1

Umar Hasyim, Toleransi dan Kemerdekaan Beragama dalam Islam Sebagai Dasar Menuju Dialog dan Kerukunan Antar Agama, \{Surabaya: Bina Ilmu, 1979\},

Alwi Shihab, Islam Inklusif Menuju Sikap Terbuka dalam Beragama, \{Bandung: Mizan, 1998\}, cet. ke-2

Syahrin Harahap, Teologi Kerukunan, JJakarta: Prenada Media Group, 2011\}, cet. ke-1

Syaikh Salim bin "ied Al-Hilali, Toleransi Islam Menurut Pandangan AlQur'an dan As-Sunnah, \{Tegal: Maktabah Salafy Press, 2001\}, cet. ke-1

Yunus Ali Muhdhar, Toleransi Kaum Muslimin dan Sikap Musuh-musuhnya, \{Surabaya: Bungul Indah, 1994\}, cet. ke-1

Republika, "Cara Beragama Muslim Indonesia Patut Dicontoh" [Jakarta, 29 Februari, 2016],

Media Indonesia, “Toleransi di Indonesia Kian Diakui Dunia” [Jakarta: 31 Maret 2017],

Media Indonesia, "Hollande Puji Toleransi Indonesia”, [Jakarta: 30 Maret 2017], 
Badan Penelitian dan Pengembangan Ham Departeman Hukum dan Ham, Evaluasi Pengaruh Kondisi Terhadap Toleransi Beragama di Indonesia, [Jakarta, 2009],

Bashori Mulyono, Ilmu Perbandingan Agama, \{Indramayu: Pustaka Sayid Sabiq, 2010\}, cet. ke-1

Ap. Budiyono HD, Membina Kerukunan Hidup Antar Umat Beriman, \{Yogyakarta: Kanisius, 1983\}, cet. ke-1, jld. 2

Andito, [Edt.], Atas Nama Agama Wacana Agama dalam Dialog Bebas Konflik, \{Bandung: Pustaka Hidayah, 1998\}, cet. ke-1

Majles Ulama Indonesia, Kerukunan Beragama dari Perspektif Negara, Ham dan Agama-agama, \{Jakarta: MUI, 1996\}, cet. ke-1

Suparman Usman, "Kemajemukan dan Kerukunan Umat Beragama Tinjauan Singkat Kemajemukan dan Kerukunan Menurut Islam dan Perundang-undangan di Indonesia”, [Makalah, Serang, 2007],

Harun Nasution, Islam Rasional Gagasan dan Pemikiran, \{Bandung: Mizan, 1996\}, cet. ke-4. 
172 | Syafi'in Mansur

Aqlania, Vol. 08, No. 02 (Juli-Desember) 2017 ISSN: 2087-8613 